\title{
On Metalepsis
}

\author{
WENDY VERONICA XIN (D)
}

E VEN before I heard about this celebration of Elaine Freedgood's work and mentorship, I was already thinking about how I'd come to know her and about the numerous ways she has shaped my writing and my writing life. This reflection was prompted, inadvertently, by Elaine herself. A little while back, Elaine wrote me an email with the always-thoughtful subject line, "How are you, my friend?" Except, Elaine had forgotten the comma after "you," so it read instead, "How are you my friend?" This message made me laugh, as did her subsequent response about leaving out that crucial comma. Elaine came to be an unusually generous mentor through the most usual of circumstances. I was first put in touch with her when she came to Berkeley to give a talk called "The Secret Life of Diegesis," five years ago. I have a vivid memory of the emails we'd exchanged about booking flights and reserving hotel rooms and all that-usually these would be somewhat tedious issues to sort through, but Elaine's typically dry humor enlivened even the driest of topics. When asked if she wanted to "be a trooper" and take a red-eye over to the West Coast, she responded, "Thanks so much. I would be a trooper if necessary but of course would rather be a pathetic middle-aged person (i.e., myself)."

Already, even at that early stage of graduate school, I could recognize that Elaine's informality and straight-shooting were rare qualities to encounter, a breath of fresh air that helped me feel, in that strange and vulnerable time, seen and heard without any risk of judgment. During our first chats at Berkeley, Elaine's graciousness made our early conversations about the value of literary criticism feel deeply intellectual rather than (on my part) prematurely or performatively professional. Whether it was talking about narratology or about Roland Barthes's The Preparation of the Novel, which I'll return to later, I got the impression that Elaine, to use one of my favorite phrases, "didn't suffer fools": that she wanted to see people's minds at work, not just how well they could

Wendy Veronica Xin is a lecturer in English at the University of California, Berkeley. She has completed a book manuscript entitled The Secret Lives of Plot and has recently published essays in New Literary History and Novel: A Forum on Fiction, among others. The working title of her second project is Third Forms: Realism, Genre, Critique. 
"master the lingo." She cared as much about critical conviction as she did about theoretical rigor.

More than all this, though, I remember being so struck by the paper that Elaine shared on "ballast" during that visit. That talk forms part of her forthcoming book, Worlds Enough: The Invention of Realism in the Victorian Novel. I had just read The Ideas in Things for the first time, and this talk extended what I found so exciting about that project: Elaine advanced a methodology that was courageous and unusual. Rather than creating homologies or dealing in expressive causalities, Elaine reveled in moments of "splitting" in the text, where its "unconscious divisions" became visible, instances akin to what Edward Said has termed "molestation," those uncomfortable moments where the illusion of narrative authority or of novelistic reality becomes a little unsettled, shamridden, and maybe a little shameful. In her brilliant second book, Elaine shows us how reading for the objects that one almost doesn't think enough of to even see, much less remark on, possesses this disruptive potential-mahogany furniture, tobacco, checked cotton curtains, etc. Objects like the barometer or the little door usually meld into the background, signifying nothing more nor less than the generic real. The realist detail exemplifies the real, subsumed by a referential function that obliterates its own objecthood. Such "reality effects," Elaine argues, "provide a low-maintenance balance for the meaningful stuff in the novel, ensuring that we can interpret realism adequately and protect it and ourselves from being overwhelmed by allegorical surfeit. It also limits the work of interpretation-only some parts of these long texts really require exegesis of any kind."

Newly illuminating these things so "little and lightly read," Elaine's work luxuriated in the ruptures and fractures, the slippages and contradictions that showed realism to be an enterprise not-always-governed by smoothness and success. This felt frightening to me at the time; she seemed to argue in the negative space of preexisting theories and critical trends (in this case, "thing theory"). She unsettles the naturalized oddness of the novel by settling into the "formal hijinks" of the text, rather than dismissing them willy-nilly as naturalized aporias of the form. Her methodology is thus most properly analogous to the ungovernable play of metonymy, what she calls the "figure of arrested development," an "interpretive open end of dizzying potential" that "threatens," "disrupt[s]," "open[s] up too many possibilities," and "expose[s] things hidden." This "metonymic imagination," as she calls it, creates a "little wreck of meaning." If, as Lyotard puts it, "Art does not say the unsayable, but 
says that it cannot say it," Elaine's books have shown me how this kind of negation can be carried out into novel theory and into historically attentive readings of high Victorian realism. ${ }^{5}$

This is all to say, perhaps, that Elaine's work is not only about the uninterrogated ramifications of reading things like the realist detail, footnotes, epigraphs, and even metalepsis against the grain, but that her work is, to me, itself fundamentally metaleptic in nature, imagining unlikely connections and contradictions between the world of the text and the world in the text, between conventional critical practice and its provocative overturning, teasing, or crossing over. Metalepsis is, according to Gérard Genette-and as we know from Elaine's work on the "colonial effect"-a "transgression" of narrative boundaries, an "intrusion of a narrator or character into a frame in which they do not belong." ${ }^{6}$ We could think of any magical-realist text in which a reader is suddenly killed by a character from the book he holds in his hands, or we could imagine less dramatic but no less significant instances of fictional characters walking into the concrete realities of our worlds: when, for example, Sherlock Holmes goes to his home in Baker Street or Daniel Deronda rows on the Thames. Elaine's article on how footnotes upset the fine line between fiction and fact makes metalepsis something more than just narratological: she writes, "To be able to violate the diegetic levels of your own life (to engage in metalepsis) is both exhilarating and probably necessary to imagining new ways of being, or to working out old ones. Narratives frame us rigidly-we know this from genre theory as well as from psychoanalysis, medicine, law, and the history of anything and everything. But narrative frames also frame us rigidly. Diegetic space is claustrophobic-ontologically and narratively. We want sometimes to be on the outside looking in, or on the outside looking out." 7

By instantiating a phenomenology against the pressures of narratological taxonomy and to parse formal markers like the realist detail and metalepsis socially and almost affectively, as Elaine does, opens up a thrilling theory of genre and of novel form, one that infuses realism with a weirdness, a self-consciousness, an embarrassment about its illusions that might shed light on how "being on the outside looking in" might feel if the novel itself were a subject in its own right. In her call for scholars of realism, in the coda to her latest book, to "decolonize the novel," Elaine now paves a path for us to revisit form and formalisms such that we can use realism's own desire for coherence to think about structures of dispossession and appropriation that deprive subjects of that very sense of continuity. Resituating ourselves in the disorderliness 
and impasses of the realist novel, we can then see how fiction might give us "an inconsistency to consider the difference between what we have and what we want, between historical actuality and a dream of its repair." 8 To borrow from Elaine, we might then begin "to restore the formal messiness of the Victorian novel before its structuralist rehabilitation" and to "read against the grain of our entrenched sense of 'realism' and 'formal coherence" in order to challenge simple homologies between literary form and other forms of form. Only then can we glean a formalist paradigm in Western literary form where genre becomes more like a gesture, a gesture of mediation in the midst of its own representational problems, antimonies, and aporias.

I remember once chatting with Elaine about Barthes's The Preparation of the Novel because some of the manuscript was on exhibit at the Centre Pompidou in 2003. There, Barthes elaborates the ways that a writer might find a balance between "the Work" and "the World." He writes, in particular, of the problem of other people when it comes to the work, something we might now euphemistically call "protecting one's time": "The 'World' is not only the General-Social; it's also the Personal-Relational. ... [T] he peculiarity of the 'Personal' ... is that it can't be generalized, synthesized; it's a collection of different cases, each of them irreducible. . . . [T] he meetings with friends are what keep you from writing, but if you itemize the collection, each friendship is worth maintaining and wants to be maintained." Here, then, is what Barthes dubs the "irresolvable contradiction": "friendship is of the order of the Incomparable, but adding all those Incomparables together, you produce a general constraint. Whence the temptation-and what's more one that's crazy because the price paid would be too high-of an All or Nothing." It is all too easy to understand what he means by this, all too simple to imagine how a writerly life might demand that the world be sacrificed to its cultivation. But what Elaine has shown me, in her capacity as a pedagogue not just at NYU but at the Prison University Project, as a mentor, as a scholar, as a friend, as a colleague, is a way out of this irresolvable contradiction, to maintain all the "Incomparables" at once.

From drop-of-the-hat emails, phone calls about this grant application or that book proposal, and meticulous readings of chapters under construction, Elaine has always been game, even amidst her own tight schedule. She has been a model of engaged, impassioned, earnest, dedicated mentorship, showing a ferocity of spirit not just in her writing but in the time she courageously carves out of her writing schedule to tend to 
the people in her life. Her unflagging optimism about her students' capacities to surprise even themselves cannot, I think, help but instill in her students all those qualities she trusts are already intrinsic to them. In this sense, Elaine is not just an imaginative scholar of metalepsis, she is its source: as if by the sheer force of her faith in our right to speak and to speak with interest, Elaine creates a discursive space where we might exceed the very frame of our own abilities. This is, I think, the best kind of metalepsis there is.

\section{Notes}

1. Freedgood, The Ideas in Things, 3.

2. Freedgood, The Ideas in Things, 9.

3. Freedgood, The Ideas in Things, 14.

4. Freedgood, The Ideas in Things, 21, 15.

5. Lyotard, Heidegger and "the jews," 47.

6. Genette, Narrative Discourse, 235; Freedgood, "Fictional Settlements," 398.

7. Freedgood, "Fictional Settlements," 399.

8. Freedgood, Worlds Enough, n.p.

9. Barthes, The Preparation of the Novel, 201.

\section{Works Cited}

Barthes, Roland. The Preparation of the Novel: Lecture Courses and Seminars at the Collège de France (1978-1979 and 1979-1980). Trans. Kate Briggs. New York: Columbia University Press, 2011.

Freedgood, Elaine. "Fictional Settlements: Footnotes, Metalepsis, the Colonial Effect." New Literary History 41, no. 2 (2010): 393-411.

- The Ideas in Things: Fugitive Meaning in the Victorian Novel. Chicago: University of Chicago Press, 2006.

- Worlds Enough: The Invention of Realism in the Victorian Novel. Princeton: Princeton University Press, 2019.

Genette, Gérard. Narrative Discourse: An Essay in Method. Trans. Jane E. Lewin. Ithaca: Cornell University Press, 1980.

Lyotard, Jean-François. Heidegger and "the jews." Trans. Andreas Michel and Mark S. Roberts. Minneapolis: University of Minnesota Press, 1990. 